\title{
Pengembangan Produk Susu yang Mengandung Kalsium, Inulin, dan Teripang sebagai Susu Kaya Prebiotik dan Kolagen
}

\author{
Dairy Product Development of Calcium, Inulin and Sea Cucumberas Milk Containing Prebiotic and Collagen
}

\author{
Almira Nadia*, Mirza Hapsari Sakti Titis Penggalih, Emy Huriyati
}

\author{
Departemen Gizi Kesehatan, Fakultas Kedokteran, Universitas Gadjah Mada Jalan Farmako, Sekip Utara, \\ Yogyakarta 55281 Indonesia \\ *Email: almira.nadia@mail.ugm.ac.id
}

Tanggal submisi: 5 Oktober 2016; Tanggal penerimaan: 7 November 2018

\begin{abstract}
ABSTRAK
Salah satu masalah kesehatan yang terjadi pada usia lanjut adalah osteoporosis. Prevalensinya di Indonesia mencapai $19,7 \%$. Asupan gizi berperan penting dalam penanganan osteoporosis. Asupan kalsium yang cukup akan memberikan dampak pada kepadatan tulang yang lebih tinggi. Penyerapan kalsium dipengaruhi oleh banyak hal. Inulin merupakan prebiotik membantu meningkatkan penyerapan kalsium dalam tubuh. Selain asupan kalsium dan penyerapannya, faktor pengisi tulang yang lain juga perlu diperhatikan. Kolagen adalah salah satu pengisi tulang selain kalsium dan fosfat. Tanpa kolagen, tulang akan mudah rapuh dan pecah. Pengembangan susu yang diperkaya kalsium, inulin, dan kolagen dari produk susu yang disebut Kalipang, berpotensi untuk membantu penanganan osteoporosis. Tujuan penelitian ini adalah untuk mengetahui mutu organoleptik dan sifat fisikokimia susu Kalipang. Penelitian ini merupakan penelitian observasionalanalitik yang terdiri dari tiga tahap. Tahap pertama adalah formulasi produk susu Kalipang yang terdiri dari 4 formula. Tahap kedua adalah pengujian mutu organoleptik produk Kalipang yang meliputi uji kesukaan terhadap warna, aroma, rasa, tekstur, serta kelarutannya. Tahap ketiga adalah pengujian sifat fisikokimia produk yang meliputi analisis kadar gula total, gula reduksi, sukrosa, protein, lemak, air, abu, kalsium, dan pH. Fomula susu Kalipang yang dibuat memiliki perbedaan tingkat kesukaan. Dari segi rasa dan keseluruhan, formula 2 paling disukai panelis. Dari segi warna, aroma, dan tekstur formula 4 paling disukai panelis. Hasil pengujian kandungan gizi menunjukkan bahwa formula 1 memiliki kadar gula total, kadar air, dan kadar inulin tertinggi. Formula 2 memiliki kadar gula reduksi, lemak, dan sukrosa tertinggi. Formula 4 memiliki kadar protein, abu, dan kalsium tertinggi. Formula 4 merupakan produk yang memiliki daya terima paling baik dan nilai gizi yang lebih unggul dibanding formula lain.
\end{abstract}

Kata kunci: Kalsium;inulin; susu; pengembangan produk; teripang

\begin{abstract}
One of the health problems that happens in elderly is osteoporosis. Its prevalence in Indonesia reached $19.7 \%$. Nutrition is one of the important parts of osteoporosis treatment. Sufficient calcium intake impacts on high bone density. Many factors affect calcium absorption. Inulin is a prebiotic that helps increase calcium absorption. Bone composition is one of the important factors. Collagen is a bone component besides calcium and phosphate, which improves fracture resistance. The research aims to determine the organoleptic and physicochemical properties of a dairy product named "Kalipang". This research is an observational analytic study done in three stages. The first stage is a dairy product "Kalipang" formulation consisting of four formulas. The second is the organoleptic test of "Kalipang" including test against color, aroma, flavor, texture, and solubility and the last step is physicochemical
\end{abstract}

DOI: http://doi.org/10.22146/agritech. 11202

ISSN 0216-0455 (Print), ISSN 2527-3825 (Online) 
properties test of products which covers the analysis of total sugar, reducing sugar, sucrose, protein, fat, water, ash, calcium, inulin, and pH. The result showed that from the aspect of flavor and overall, panelists prefer formula 2 than the other formulas. Based on the color, aroma, and texture, panelists prefer formula 4 than the others. Nutritional content test results showed that formula 1 has the highest level of total sugar, water, and inulin. Formula 2 has the highest level of reducing sugar, fat, and sucrose. Formula 4 has the highest level of protein, ash, and calcium. Formula 4 meets the organoleptic acceptance and has a better nutritional content than the others.

Keywords: Calcium; inulin; milk; product development; sea cucumber

\section{PENDAHULUAN}

Salah satu masalah kesehatan yang terjadi pada usia lanjut adalah osteoporosis. Osteoporosis sering disebut sebagai silet disease karena penurunan massa tulang terjadi tanpa disertai gejala. Apabila telah mencapai tahap lanjut, gejala tersebut baru bisa dikenali (Jahari \& Prihartini, 2007). Di Indonesia, prevalensi osteoporosis mencapai $19,7 \%$. Osteoporosis yang terjadi pada wanita dengan usia di atas 50 tahun mencapai $32,2 \%$ sedangkan pada pria dengan usia di atas 50 tahun mencapai 28,8\% (Junaidi, 2007).

Asupan gizi berperan penting dalam penanganan osteoporosis. Menurut penelitian yang dilakukan oleh Prihatini dkk (2010), proporsi seseorang yang beresiko osteoporosis dengan kecukupan protein, kalsium, fosfor, dan magnesium $<70 \%$ AKG lebih tinggi daripada proporsi orang yang memiliki kecukupan zat gizi tersebut $>70 \%$. Faktor gaya hidup dan kebiasaan tidak minum susu juga meningkatkan risiko osteoporosis. Konsumsi susu pada remaja wanita akan memeberikan kepadatan tulang yang lebih tinggi (Du, 2002). Berdasarkan hal tersebut diketahui bahwa kalsium memiliki peran penting dalam pembentukan tulang.

$$
\text { Untuk memaksimalkan penanganan }
$$

osteoporosis perlu diperhatikan komponen-komponen gizi yang mendukung dari segi nutrisi salah satunya adalah pemanfaatan prebiotik yaitu inulin. Inulin dapat membantu meningkatkan penyerapan kalsium berkaitan dengan kelarutan mineral yang disebabkan oleh adanya peningkatan bakteri yang memproduksi asam lemak rantai pendek. Produk fermentasi bakteri terutama laktat dan butirat akan memperluas permukaan absorbsi sehingga akan meningkatkan penyerapan kalsium pada usus (Scholz-ahrens dkk., 2007). Suplementasi inulin sebanyak $8 \mathrm{~g}$ selama 8 minggu memberikan hasil pada peningkatan absorbsi kalsium sebanyak $3 \%$ pada 13 subjek. Sebanyak 8 subjek memberikan peningkatan absorbi kalsium yang lebih tinggi yaitu dari $22,7 \%$ menjadi 31\% (Abrams dkk., 2007).

Salah satu unsur penting dalam proses pembentukan tulang adalah kolagen. Fungsi kolagen adalah sebagai pengikat jaringan dalam pertumbuhan tulang dan kulit. Jika tidak ada kolagen, tulang akan mudah rapuh dan pecah (Astawan, 2008). Salah satu sumber daya laut yang mengandung kolagen adalah teripang. Kandungan kolagen yang terdapat dalam tubuh teripang mencapai $80 \%$ dari total protein yang dimilikinya. Konsumsi $3 \mathrm{~g}$ teripang kering per hari dapat mengurangi arthralgia (Chen, 2003). Penelitian oleh Guillerminet dkk. (2010) mengungkapkan bahwa ransum tikus yang diperkaya kolagen selama 12 minggu meningkatkan aktivitas osteoblast dan menurunnya diferensiasi dan pematangan osteoklas. Proses tersebut akan menstimulasi pembentukan dan mineralisasi tulang.

Penelitian oleh Penggalih (2015) bertujuan untuk mengetahui efek pemberian prebiotik, kalsium, dan kolagen terhadap pembentukan massa tulang tikus baik yang sehat maupun dengan osteoporosis. Hasil dari penelitian ini adalah pakan yang mengandung pakan standar, inulin, dan teripang memiliki hasil yang lebih baik dalam memperbaiki mineralisasi tulang tikus.

Dari penjelasan di atas, dapat diketahui bahwa pengembangan produk berbahan dasar kalsium, inulin, dan teripang sangat berpotensi untuk dilakukan agar dapat bermanfaat bagi masyarakat luas terutama untuk kesehatan tulang. Namun, saat ini belum banyak dikembangkan suatu produk yang mengandung ketiga bahan tersebut. Oleh karena itu, peneliti ingin membuat produk berupa susu yang mengandung ketiga komponen tersebut, kemudian menguji mutu organoleptik dan sifat fisikokimianya. Susu merupakan produk makanan yang mudah dan praktis untuk dikonsumsi serta diminati oleh berbagai kalangan. Dengan adanya pengembangan produk tersebut, diharapkan dapat menjadi salah satu alternatif makanan yang bermanfaat untuk masyarakat.

\section{METODE PENELITIAN}

\section{Bahan dan Alat}

Bahan-bahan yang digunakan dalam penelitian ini adalah High Calcium Skim Milk Powder varian rasa plain dan coklat (AnleneGold), inulin yang didapatkan dari salah satu perusahaan susu, sukrosa, dan bubuk 
teripang kering yang didapatkan dari produsen teripang kering di Madura, esens rasa vanila dan jeruk, bubuk kakao, serta gula cair jenis sukrosa. Adapun alat-alat yang dipakai dalam penelitian ini adalah blender drymill (Philips HR2815, Belanda) ukuran rumah tanggauntuk mencampur bahan susu, timbangan analitik (Idealife IL211s, Japan) dengan ketelitian $1 \mathrm{~g}$, dan alat-alat untuk pengujian fisikokimia di laboratorium.

\section{Metode penelitian}

Jenis penelitian ini adalah observasi onalanalitik. Penelitian dilakukan dari bulan September 2015 sampai Februari 2016 dan terdiri dari tiga tahap. Tahap pertama yaitu pembuatan susu Kalipang. Susu dibuat dengan mengembangkan formula original dan dibuat sebanyak 4 perlakuan dan disajikan dalam bentuk cair. Formula original terdiri dari 19,5 g High CalciumSkim Milk Powder rasa plain, $1,5 \mathrm{~g}$ inulin, $6 \mathrm{~g}$ teripang, dan $3 \mathrm{~g}$ sukrosa. Pencampuran menggunakan blender bahan kering (drymill) selama 2 menit. Pada penelitian sebelumnya, komposisi formula original memiliki efek terbaik untuk mineralisasi tulang. Pengembangan empat formula susu dilakukan untuk menguji sifat organoleptik agar produk dapat diterima oleh masyarakat dengan cara variasi bahan tambahan pangan berupa bubuk kakao. Formula 1 dibuat dengan komposisi sama dengan formula original. Formula 2 dibuat dengan mengganti susu rasa plain dengan rasa coklat. Formula 3 dibuat dengan menambahkan bubuk kakao $2 \mathrm{~g}$ pada formula original, sedangkan formula 4 ditambah $5 \mathrm{~g}$ bubuk kakao.

Tahap kedua terdiri dari pengujian mutu organoleptik susu oleh 3 orang panelis terlatih dan 48 panelis agak terlatih. Pengujian pertama dilakukan oleh panelis terlatih dengan mengisi kuesioner dan menilai tingkat kesukaan panelis terhadap warna, aroma, rasa, tekstur dengan skala $1-4$. Selain itu juga dinilai kelarutan susu dengan melihat apakah masih terbentuk endapan pada susu dan dinilai dengan skala kelarutan 1

- 6. Semua formula masih memiliki mutu organoleptik yang rendah sehingga perlu diperbaiki dengan menambahkan bahan tambahan pangan pada semua formula yang terlah dilarutkan. Semua formula diberi tiga perlakuan sebagai berikut (1) penambahan gula cair $10 \mathrm{~mL}$ (2) penambahan gula cair $10 \mathrm{~mL}$ dan esens jeruk $0,5 \mathrm{~mL}$ (3) penambahan gula cair $10 \mathrm{~mL}$ dan esens vanila $0,5 \mathrm{~mL}$. Panelis terlatih menilai formula dengan penambahan bahan tambahan terbaik yang kemudian diuji mutu organoleptiknya oleh panelis agak terlatih. Tahap ketiga yaitu pengujian sifat fisikokimia susu yang terdiri dari pengujian kadar gula total, gula reduksi, sukrosa dengan metode Nelson Somogyi, pengujian kadar protein dengan metode Kjeldahl, pengujian kadar lemak dengan metode Mojonnier, pengujian kadar air dengan metode termogravimetri, pengujian kadar abu dengan metode pengabuan kering, pengujian kadar kalsium dengan metode spektrofotometri serapan atom, pengujian kadar inulin dengan metode HPLC, dan pengujian $\mathrm{pH}$ dengan $\mathrm{pH}$ meter.

\section{Analisis Statistik}

Analisis data dilakukan dengan menggunakan uji Friedman untuk analisis data uji kesukaan. Jika terdapat perbedaan bermakna $(p<0,05)$, maka dilanjutkan dengan uji posthoc Wilcoxon. Pengujian kandungan gizi menggunakan uji one-way ANOVA karena data terdistribusi normal. Jika terdapat perbedaan bermakna maka dilanjutkan dengan posthocDuncan.

\section{HASIL DAN PEMBAHASAN}

\section{Pembuatan Susu Kalipang}

Pada tahap ini dihasilkan produk susu Kalipang dalam bentuk bubuk. Formula 1 dan 2 disajikan sebanyak $30 \mathrm{~g}$, formula 3 disajikan sebanyak $32 \mathrm{~g}$, formula 4 disajikan sebanyak $35 \mathrm{~g}$. Kemudian keempat formula tersebut disajikan dalam bentuk cair dengan penambahan gula cair, esens vanila, dan esens jeruk seperti yang telah tercantum dalam metode.

\section{Pengujian Mutu Organoletik oleh Panelis Terlatih}

Masing- masing formula yang telah diberi tambahan gula cair $10 \mathrm{~mL}$, esens jeruk $0,5 \mathrm{~mL}$, dan esens vanila $0,5 \mathrm{~mL}$ diuji cita rasanya untuk memperoleh formula dengan penambahan bahan tambahan terbaik. Semua formula ditambahkan gula cair $10 \mathrm{~mL}$ untuk mengurangi rasa asin yang dihasilkan dari teripang. Berdasarkan pengujian oleh panelis terlatih, sifat organoleptik formula 1 meningkat ketika ditambahkan esens jeruk sedangkan formula 2 ditambah esens vanila. Formula 3 dan 4 cita rasanya meningkat ketika hanya ditambahkan gula cair karena komposisi awalnya formula tersebut sudah ditambahkan kakao bubuk sebanyak $2 \mathrm{~g}$ pada formula 3 dan $5 \mathrm{~g}$ pada formula 4 .

Formula 1: penambahan gula cair $10 \mathrm{~mL}+$ esens jeruk $0,5 \mathrm{~mL}$

Formula 2: penambahan gula cair $10 \mathrm{~mL}$ + esens vanila $0,5 \mathrm{~mL}$

Formula 3 : penambahan gula cair $10 \mathrm{~mL}$ Formula 4 : penambahan gula cair $10 \mathrm{~mL}$ 


\section{Pengujian Mutu Organoleptik}

Sebanyak 48 panelis menilai setiap formula yang disajikan sebanyak $50 \mathrm{~mL}$ untuk masing-masing sampel. Pada pengujian ini dipakai 6 poin skala hedonik yaitu sangat tidak suka, tidak suka, agak tidak suka, agak suka, suka, sangat suka. Nilai terkecil menunjukkan bahwa formula tidak disukai dan nilai terbesar menunjukkan formula yang paling disukai. Hasil pengujian dapat dilihat pada Tabel 1 . Nilai $p<0,001$ menunjukkan bahwa terdapat perbedaan tingkat kesukaan pada setiap formula. Hasil analisis menunjukkan bahwa dari segi warna, aroma, dan tekstur, formula 4 paling disukai oleh panelis. Sedangkan dari segi rasa dan keseluruhan, formula 2 paling disukai panelis. Penilaian kelarutan susu dilakukan secara umum untuk semua formula. Hasil pengujian kelarutan secara subjektif menunjukkan bahwa semua formula memiliki sifat agak sukar larut. Grafik pengujian kelarutan dapat dilihat pada Gambar 1.

Uji organoleptik pada suatu produk perlu dilakukan untuk menilai seberapa besar minat konsumen terhadap produk yang dihasilkan. Pengujian ini dilakukan untuk mengetahui penilaian terhadap produk yang diujikan (Rakhmah, 2012). Hasil uji statistik pengujian sifat organoleptik formula susu Kalipang memberikan hasil $p<0,001$ menunjukkan bahwa terdapat perbedaan tingkat kesukaan warna, aroma, rasa, tekstur, dan keseluruhan susu.

Dilihat dari segi warna formula 4 memiliki warna yang paling disukai oleh panelis. Menurut Nahak dkk. (2014), tingkat penerimaan atau penolakan suatu

Tabel 1. Data hasil analisis pengujian sifat organoleptik

\begin{tabular}{cccccc}
\hline Perlakuan & Warna & Aroma & Rasa & Tekstur & Keseluruhan \\
\hline Formula 1 & $1,96 \pm 0,69^{\mathrm{a}}$ & $1,87 \pm 0,72^{\mathrm{a}}$ & $1,60 \pm 0,57^{\mathrm{a}}$ & $2.24 \pm 0,73^{\mathrm{a}}$ & $1,74 \pm 0,57^{\mathrm{a}}$ \\
Formula 2 & $2,58 \pm 0,71^{\mathrm{b}}$ & $2,78 \pm 0,66^{\mathrm{b}}$ & $2,34 \pm 0,76^{\mathrm{bc}}$ & $2,61 \pm 0,68^{\mathrm{b}}$ & $2,54 \pm 0,72^{\mathrm{b}}$ \\
Formula 3 & $3,17 \pm 0,53^{\mathrm{c}}$ & $2,26 \pm 0,61^{\mathrm{c}}$ & $2,02 \pm 0,61^{\text {bd }}$ & $2,74 \pm 0,61^{\text {bc }}$ & $2,34 \pm 0,56^{\mathrm{bc}}$ \\
Formula 4 & $3,23 \pm 0,72^{\mathrm{c}}$ & $2,84 \pm 0,73^{\mathrm{b}}$ & $2,00 \pm 0,86^{\mathrm{b}}$ & $2,76 \pm 0,70^{\text {bc }}$ & $2,34 \pm 0,64^{\mathrm{bc}}$ \\
\hline
\end{tabular}

Keterangan:

Data disajikan dalam mean \pm SD tanpa pengulangan

Huruf superscript yang sama pada kolom yang sama menunjukkan tidak ada perbedaan nyata

Formula original : $19,5 \mathrm{~g}$ High CalciumSkim MilkPowder + inulin $1,5 \mathrm{~g}+$ teripang $6 \mathrm{~g}+$ sukrosa $3 \mathrm{~g}$

Formula 1 : formula original + gula cair $10 \mathrm{~mL}+$ esens jeruk $0,5 \mathrm{~mL}$

Formula 2 : formula original + gula cair $10 \mathrm{~mL}+$ vanila 0,5 $\mathrm{mL}$

Formula 3 : formula original + bubuk kakao $2 \mathrm{~g}+$ gula cair $10 \mathrm{~mL}$

Formula 4 : formula original + bubuk kakao $5 \mathrm{~g}+$ gula cair $10 \mathrm{~mL}$

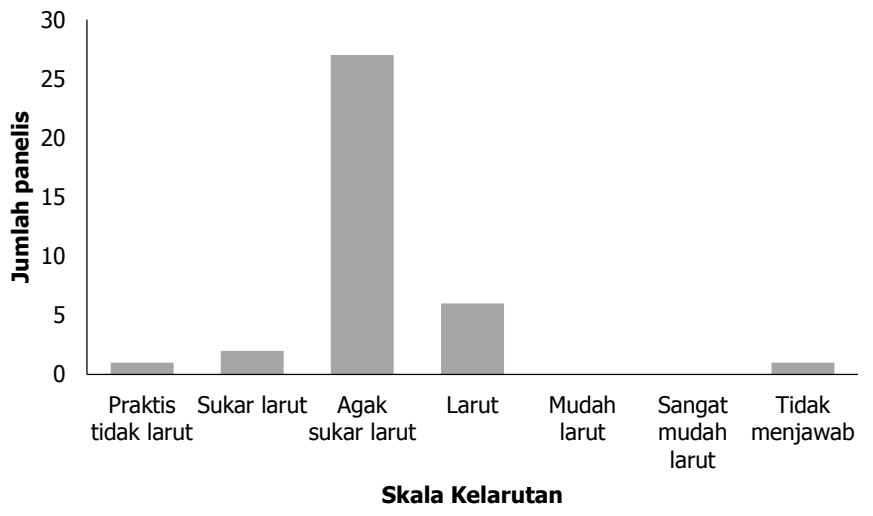

Gambar 1. Hasil pengujian kelarutan susu

produk dipengaruhi oleh warna. Salah satu faktor yang menyebabkan suatu bahan makanan memiliki warna adalah penambahan zat warna baik alami maupun buatan. Zat tersebut termasuk dalam golongan bahan aditif makanan (Winarno, 2004). Formula 1 berwarna putih kekuningan karena ditambahkan esens jeruk, sedangkan susu lain berwarna coklat. Pada umumnya susu mempunyai warna putih kebiruan sampai kuning kecoklatan. Warna putih dibentuk akibat penyebaran koloid lemak, kalsium kaseinat, dan kalsium fosfat. Sedangkan warna kuning dibentuk dari karoten dan riboflavin (Buckle, 2010).

Aroma adalah reaksi dari makanan yang dapat mempengaruhi konsumen sebelum makanan tersebut dinikmati (West dkk., 2006). Dari segi aroma, panelis paling menyukai aroma formula 4. Formula tersebut adalah formula original yang ditambahkan bubuk kakao sebanyak $5 \mathrm{~g}$ dan gula cair. Berdasarkan hasil tersebut, penambahan coklat yang lebih banyak pada formula 4 dapat menyamarkan aroma amis dari teripang sehingga memperbaiki mutu produk. Adanya kandungan sukrosa juga dapat memperbaiki aroma. Hasil pengujian kadar sukrosa menunjukkan bahwa kadar sukrosa tertinggi dimiliki oleh formula 2. Menurut Nicol (1979), sukrosa dapat memperbaiki aroma dan cita rasa dengan cara membentuk keseimbangan yang lebih baik antara keasaman, rasa pahit, dan rasa asin.

Hasil pengujian dari segi rasa menunjukkan bahwa formula 2 adalah formula yang paling disukai panelis. Formula 2 menggunakan High CalciumSkim Milk rasa coklat, sedangkan formula lain menggunakan rasa plain. Selain itu, ada penambahan gula cair dan esens vanila untuk memperbaiki mutunya. Kadar sukrosa yang lebih tinggi pada formula 2 dapat memperbaiki rasa susu karena sukrosa dapat memperbaiki cita rasa (Nicol, 1979). Adanya penambahan gula cair pada seluruh formula digunakan untuk menekan rasa 
asin produk susu. Hal ini berkaitan dengan interaksi komponen rasa lain dengan komponen rasa primer. Gula yang ditambahkan akan memperbaiki rasa asin pada susu (Zuhra, 2006). Pada penelitian oleh Fajriyah (2010), penambahan sukrosa $6 \%$ pada yoghurt lebih disukai panelis.

Hasil pengujian dari segi tekstur menunjukkan bahwa panelis paling menyukai tekstur formula 4. Tekstur dan konsistensi suatu bahan akan mempengaruhi cita rasa produk. Perubahan tekstur atau viskositas bahan dapat mengubah rasa dan bau yang timbul. Perubahan tersebut dapat mempengaruhi kecepatan timbulnya rangsangan sel reseptor olfaktori dan kelenjar air liur (Winarno, 2004). Menurut Zuhra (2006), kekentalan suatu produk dapat mempengaruhi aroma dan rasa produk. Semakin kental suatu bahan maka intensitas penerimaan dari segi aroma dan rasa semakin berkurang.

Penilaian tingkat kesukaan susu secara keseluruhan menunjukkan bahwa formula 2 adalah susu yang paling disukai panelis. Sebagian besar panelis menuliskan komentar bahwa beberapa produk masih terasa asin yang berasal dari teripang dan aromanya menyengat. Hal ini menunjukkan bahwa daya terima susu Kalipang masih rendah sehingga mutu organoleptik susu masih perlu diperbaiki.

Penilaian terhadap kelarutan susu menunjukkan bahwa produk agak sukar larut karena masih terdapat endapan. Hal ini berkaitan dengan teripang bubuk yang ukuran partikelnya masih lebih besar dari susu bubuk, inulin, maupun sukrosa. Saat susu diseduh, teripang tidak dapat larut bersama susu sehingga membentuk endapan. Teripang merupakan bahan yang kaya akan kolagen. Sifat kolagen antara lain tidak larut dalam larutan asam maupun alkali, tahan terhadap enzim tripsin dan chimotripsin (Kirk \&Othmer, 1996).

\section{Pengujian Sifat Fisikokimia}

Analisis data kandungan gizi susu menggunakan one-way ANOVA dalam program SPSS kemudian dilanjutkan dengan multiplecomparison $L S D$ dan posthocDuncan. Hasil pengujian tersebut memiliki $p<0,05$ yang menunjukkan bahwa terdapat perbedaan kandungan gula total, gula reduksi, protein, lemak, air, dan abu pada setiap formula. Formula 1 memiliki kadar gula total dan kadar air tertinggi. Kadar gula reduksi dan kadar lemak tertinggi dimiliki oleh formula 2. Kadar protein dan abu teringgi dimiliki oleh formula 4. Kadar $\mathrm{pH}$ masing-masing susu relatif sama yaitu dalam rentang $6,53-6,77$. Data hasil pengujian kalsium menunjukkan bahwa kadar tertinggi dimiliki oleh formula 4, sedangkan inulin tertinggi dimiliki oleh formula 1 dan kadar sukrosa tertinggi dimiliki oleh formula 2. Dari hasil pengujian protein di LPPT dengan metode Kjeldahl, formula 1 dan 4 memiliki kadar protein tertinggi yaitu 4,43\% b/v. Pengujian kadar lemak di LPPT dengan metode Gravimetri menunjukkan bahwa formula 4 memiliki kadar lemak tertinggi.

Berdasarkan hasil pengujian sifat fisikokimia, formula 1 memiliki kadar gula total tertinggi. Sedangkan kadar gula reduksi dan sukrosa tertinggi dimiliki oleh formula 2. Sukrosa merupakan polimer dari molekul glukosa dan fruktosa melalui ikatan glikosidik (Winarno, 2004). Menurut Hidayat dan Ken (2004), gula yang ditambahkan dalam bahan pangan dengan konsentrasi yang tinggi akan mengakibatkan jumlah air bebas yang ada dalam bahan pangan tersebut menjadi tidak tersedia bagi pertumbuhan mikroorganisme. Gula reduksi (glukosa dan fruktosa) mempunyai kelarutan yang tinggi sehingga akan meningkatkan kadar zat padat terlarut dalam suatu larutan (Winarno, 2004). Adanya penambahan gula dalam bahan makanan akan mengurangi rasa asin (Zuhra, 2006).

Hasil pengujian kandungan protein menunjukkan bahwa formula 4 memiliki kadar protein tertinggi. Menurut SNI 01-4231-1996 tentang Susu Formula, syarat kadar protein minimum susu adalah minimal $3 \mathrm{~g}$ setiap 100 kkal. Formula susu Kalipang tidak diuji kandungan energinya sehingga kadar protein susu Kalipang tidak bisa dibandingkan dengan SNI susu formula. Menurut SNI Susu Segar (2011), minimal kandungan protein pada susu adalah 2,8\%. Berdasarkan syarat tersebut, maka kadar protein semua formulasi susu telah memenuhi standar. Susu merupakan sumber protein yang bermutu tinggi. Protein susu terutama sangat kaya akan lisin, yaitu salah satu asam amino esensial yang sangat dibutuhkan tubuh (Widodo, 2002). Susu Kalipang merupakan susu yang mengandung teripang. Kadar protein teripang cukup tinggi mencapai $82 \%$ per $100 \mathrm{~g}$ teripang kering (Astawan, 2008).

Hasil pengujian menunjukkan kadar lemak susu berkisar antara 0,43-1,07\%. Menurut SNI 01-42311996 tentang Susu Formula, syarat kadar lemak minimal $3 \mathrm{~g}$ dan maksimal $6 \mathrm{~g}$ setiap $100 \mathrm{kkal}$. Formula susu Kalipang tidak diuji kandungan energinya sehingga kadar lemak susu Kalipang tidak bisa dibandingkan dengan SNI susu formula. Menurut SNI 3141.1:2011, kadar lemak minumum susu segar adalah $3 \%$. Berdasarkan hal tersebut, kadar lemak semua formula tidak sesuai dengan syarat tersebut. Hal ini disebabkan oleh penggunaan bahan dasar susu bubuk berupa High Calciums kim Milk Powder. Susu tersebut merupakan susu tinggi kalsium rendah lemak (susu skim). Susu skim merupakan bagian susu yang dipisahkan setelah 
krim susu diambil. Susu ini mempunyai nilai kalori yang rendah karena mengandung 55\% dari semua energi susu. Susu skim mengandung zat gizi yang terkandung dalam susu kecuali lemak dan vitamin larut lemak (Buckle, 2010).

Kadar air susu berdasarkan hasil pengujian berkisar antara 77,67 - 78,91\%. Kadar air tertinggi dimiliki oleh formula 1 sedangkan kadar air terendah dimiliki oleh formula 4. Formula 1 merupakan susu bubuk disajikan sebanyak $30 \mathrm{~g}$ per sajian kemudian dilarutkan dalam $200 \mathrm{~mL}$ air. Sedangkan formula 4 disajikan sebanyak 35 $\mathrm{g}$ dan dilarutkan dalam $200 \mathrm{~mL}$ air sehingga formula 4 lebih kental dibandingkan dengan formula susu lain. Air merupakan medium pendispersi lemak dan komponen terlarut dalam air susu (Mirdhayati dkk., 2007). Secara umum, kandungan air dalam susu berkisar antara 80 90\% (Maheswari, 2004).

Kadar abu susu berkisar antara 1,50 - 1,94\%. Kadar abu tertinggi dimiliki oleh formula 4. Adanya kadar abu menunjukkan bahwa susu mengandung mineral. Kadar abu dalam susu bubuk tidak berlemak adalah 1,5\% (Sudarmadji, 2010). Kadar abu dihitung dari kandungan mineral yang terdapat dalam susu. Sejumlah susu yang dikeringkan dan dibakar akan menyisakan zat-zat anorganik yang dikenal sebagai mineral susu (Mirdhayatidkk., 2007). Mineral yang banyak terkandung dalam susu antara lain kalsium dan fosfor (Koswara, 2009).

Berdasarkan hasil pengujian keasaman susu $(\mathrm{pH})$, kadar $\mathrm{pH}$ masing-masing susu berada pada rentang 6,53 $-6,77$. Hal ini sudah sesuai dengan SNI 3141.1:2011. Dalam standar tersebut disebutkan bahwa $\mathrm{pH}$ untuk susu segar berkisar antara 6,3-6,8. pH mempunyai skala 1-14. Skala 0 - 7 memiliki sifat asam sedangkan skala 7 - 14 memiliki sifat basa. Pada prinsipnya $\mathrm{pH}$ susu bersifat netral. Sifat netral tersebut dapat disebabkan karena adanya kasein, buffer, fosfat, dan sitrat. Adanya kenaikan dan penurunan $\mathrm{pH}$ ditimbulkan dari hasil konversi laktosa menjadi asam laktat oleh mikroorganisme aktivitas enzimatik (Manik, 2006).

Hasil pengujian kadar kalsium menunjukkan bahwa kadar tertinggi dimiliki oleh formula 4. Hasil pengujian kandungan kalsium berkisar antara 1434,61 $\mathrm{mg} / \mathrm{kg}-2314,94 \mathrm{mg} / \mathrm{kg}$. Formula 4 merupakan formula yang ditambahkan bubuk kakao sebanyak $5 \mathrm{~g}$. Menurut Wahyudi dkk. (2008), bubuk kakao memiliki kandungan kalsium sebanyak 169,45 mg per $100 \mathrm{~g}$ bahan. Oleh karena itu, kandungan kalsium pada formula 4 lebih banyak karena adanya penambahan bubuk kakao yang lebih banyak pada formula tersebut.

Kadar inulin susu Kalipang berdasarkan hasil pengujian berkisar antara $1,47-2,98 \%$. Inulin tergolong dalam prebiotik. Salah satu manfaat inulin adalah meningkatkan absorbsi kalsium dan mineralisasi tulang. Penelitian yang dilakukan oleh Griffin dkk. (2002) menunjukkan bahwa remaja putri yang diberikan tambahan asupaninulin sebanyak $8 \mathrm{~g}$ per harinya secara signifikan meningkatkan absorbsi kalsium dibandingkan dengan yang tidak diberi tambahan inulin. Perbedaan kandungan inulin tidak mempengaruhi aroma dan rasa susu karena inulin memiliki karakteristik tidak berbau dan tidak berasa (Roberfroid, 2005). Hal ini sejalan dengan penelitian oleh Desnilasari dan Lestari (2014) bahwa penambahan inulin pada puree pisang ambon tidak memberikan perbedaan signifikan pada sifat organoleptik produk.

Tabel 2. Data hasil analisis pengujian analisis proksimat

\begin{tabular}{cccccccc}
\hline Perlakuan & Mean & Air (\%) & Abu (\%) & pH \\
\cline { 2 - 7 } & Gula total (\%) & $\begin{array}{c}\text { Gula reduksi } \\
(\%)\end{array}$ & Protein (\%) & Lemak (\%) & Air & & \\
\hline Formula 1 & $10,96 \pm 0,01^{\mathrm{a}}$ & $5,10 \pm 0,16^{\mathrm{ab}}$ & $3,48 \pm 0,14^{\mathrm{a}}$ & $0,45 \pm 0,05^{\mathrm{ac}}$ & $78,91 \pm 0,70^{\mathrm{a}}$ & $1,74 \pm 0,01^{\mathrm{a}}$ & $6,59 \pm 0,01^{\mathrm{ab}}$ \\
Formula 2 & $8,50 \pm 0,05^{\mathrm{b}}$ & $5,45 \pm 0,08^{\mathrm{a}}$ & $3,31 \pm 0,03^{\mathrm{a}}$ & $1,07 \pm 0,05^{\mathrm{b}}$ & $77,77 \pm 0,70^{\mathrm{b}}$ & $1,50 \pm 0,02^{\mathrm{b}}$ & $6,53 \pm 0,00^{\mathrm{a}}$ \\
Formula 3 & $10,83 \pm 0,11^{\mathrm{c}}$ & $4,80 \pm 0,19^{\mathrm{b}}$ & $4,15 \pm 0,04^{\mathrm{b}}$ & $0,48 \pm 0,07^{\mathrm{ac}}$ & $77,94 \pm 0,70^{\mathrm{c}}$ & $1,87 \pm 0,01^{\mathrm{c}}$ & $6,59 \pm 0,00^{\mathrm{b}}$ \\
Formula 4 & $10,88 \pm 0,07^{\mathrm{d}}$ & $4,24 \pm 0,07^{\mathrm{c}}$ & $4,29 \pm 0,09^{\mathrm{b}}$ & $0,67 \pm 0,15^{\mathrm{c}}$ & $77,67 \pm 0,02^{\mathrm{d}}$ & $1,94 \pm 0,03^{\mathrm{d}}$ & $6,77 \pm 0,01^{\mathrm{c}}$ \\
$P$ & $<0,05$ & $<0,05$ & $<0,05$ & $<0,05$ & $<0,05$ & $<0,05$ & $<0,05$ \\
\hline
\end{tabular}

Keterangan:

Data disajikan dalam mean untuk 2 kali pengulangan

Huruf superscript yang sama pada kolom yang sama menunjukkan tidak ada perbedaan nyata

Pengujian dilakukan di Laboratorium PAU UGM dan FTP UGM 
Tabel 3. Data hasil pengujian inulin, kalsium, sukrosa, protein, lemak **

\begin{tabular}{cccccc}
\hline Perlakuan & Kalsium* $(\mathrm{mg} / \mathrm{kg})$ & Inulin* $(\%)$ & Sukrosa* $(\%)$ & Protein* $\%$ b/v) & Lemak* (\%) \\
\hline Formula 1 & 1801,78 & 2,98 & 0,45 & 4,43 & 0,39 \\
Formula 2 & 1434,61 & 1,47 & 2,75 & 2,13 & 0,43 \\
Formula 3 & 2197,99 & 2,34 & 0,52 & 2,47 & 0,39 \\
Formula 4 & 2314,94 & 2,86 & 0,50 & 4,43 & 0,44 \\
\hline
\end{tabular}

Keterangan:

* Data disajikan tanpa pengulangan

** Pengujian dilakukan di Laboratorium LPPT UGM

\section{Produk Susu Kalipang}

Susu Kalipang dibuat dengan tujuan mengembangkan makanan untuk pencegahan osteoporosis. Susu ini berbahan dasar susu tinggi kalsium, inulin, dan teripang dimanainulin dapat meningkatkan absorbsi kalsium. Teripang yang digunakan mengandung kolagen yang memiliki peran penting dalam pembentukan tulang (Robling dkk., 2006). Menurut AKG 2013, kebutuhan kalsium harian adalah 1000-1200 mg per hari, sedangkan rata-rata asupan kalsium orang Indonesia $289 \mathrm{mg}$ per hari (Permatasari, 2011). Berdasarkan analisis kandungan gizi formula susu Kalipang, maka susu tersebut dapat dikonsumsi sebanyak 2 porsi dalam sehari seperti saran penyajian pada susu komersial yang ada di pasaran, dengan asumsi $300 \mathrm{mg}$ kalsium sudah terpenuhi dari makanan lain.

Pada penelitian ini, sumber kolagen didapatkan dari teripang bubuk. Kolagen merupakan protein yang menjadi penyusun utama tulang (Baron, 2006). Dalam $100 \mathrm{~g}$ teripang kering, 82\%-nya merupakan protein. Sejumlah protein tersebut merupakan kolagen sebanyak $80 \%$. Oleh sebab itu, kandungan kolagen dalam $30 \mathrm{~g}$ sajian dapat diperkirakan:

1. Penambahan teripang per $30 \mathrm{~g}$ sajian $=6 \mathrm{~g}$

2. Perkiraan kandungan kolagen

$=6 / 100 \times 80 \% \times 82 \%=3,936 \mathrm{~g}$

Teripang merupakan sumber mukopolisakarida terutama chondroitin yang memiliki fungsi untuk mengurasi rasa nyeri tulang (Kustiariyah, 2007). Menurut Dharmananda (2003), konsumsi $3 \mathrm{~g}$ teripang kering per dapat mengurangi arthralgia secara signifikan. Studi pada manusia yang dilakukan Iwai dkk. (2005) memberikan hasil bahwa konsumsi 9,4-23 g kolagen dalam bentuk gelatin hidrolisat akan meningkatkan kadar asam amino penyusun kolagen yaitu hidroksiprolin.

Untuk menentukan formula mana yang memiliki daya terima dan nilai gizi yang lebih baik, maka dilakukan scoring dengan nilai $1-4$ terhadap sifat organoleptik dan fisikokimia untuk masing-masing formula. Nilai terbesar diberikan untuk formula dengan hasil pengujian sifat organoletik dan fisikokimia terbaik. Berdasarkan hasil penilaian, formula 4 memiliki sifat organoleptik dan fisikokimia yang lebih unggul dibandingkan dengan formula lain. Namun, dari hasil analisis data terhadap rasa, formula 4 masih memiliki kelemahan. Oleh sebab itu, formula 4 perlu diperbaiki lagi dari segi rasa agar daya terimanya meningkat.

Pada penelitian yang dilakukan oleh Astuti (2012), peneliti menggunakan jahe untuk menghilangkan rasa amis pada susu yang akan dibuat menjadi keju. Dengan demikian, untuk memperbaiki cita rasa fomula 4 dapat ditambahkan ekstrak jahe untuk memperbaiki cita rasanya. Selain itu, proses pencampuran bahan juga perlu diperbaiki agar bahan baku susu dapat tercampur secara homogen. Pada proses pengayakan bubuk teripang sebaiknya digunakan ayakan dengan nilai mesh (skala kerapatan) yang lebih besar sehingga bubuk teripang yang dihasilkan semakin halus. Menurut komentar panelis, formula 1 memiliki warna yang tidak disukai karena tidak seragam yang menandakan proses pencampuran kurang baik (Winarno, 2004).

\section{KESIMPULAN}

Formulasi susu Kalipang terpilih yang ditinjau dari daya terima dan kandungan gizi paling unggul dan terpilih adalah formula 4 . Formula terpilih tersebut memiliki komposisi yang terdiri atasi 19,5 High Calcium Skim Milk Powder rasa plain, 1,5 g inulin, $6 \mathrm{~g}$ teripang, 3 gsukrosa, $5 \mathrm{~g}$ bubuk kakao, dan $10 \mathrm{~mL}$ gula cair. Fomula 4 memiliki kandungan gula total $10,88 \pm 0,07 \%$, protein $4,29 \pm 0,09 \%$, lemak $0,67 \pm 0,15 \%$, air $77,67 \pm 0,02 \%$, abu 1,94 $\pm 0,03 \%$, kalsium 2314,94 mg/kg, inulin 2,86\%, dan $\mathrm{pH} 6,77 \pm 0,01$.

\section{UCAPAN TERIMA KASIH}

Peneliti mengucapkan terima kasih kepada PT Indofood Sukses Makmur Tbk. Yang mendanai penelitian 
ini melalui program Indofood Riset Nugraha serta segala pihak yang membantu pelaksanaan penelitian. Ucapan terima kasih terutama ditujukan kepada pemberi dana penelitian atau donatur.

\section{DAFTAR PUSTAKA}

Astawan, M. (2008). Sehat dengan Hidangan Hewani. Jakarta: PenebarSwadaya.

Abrams, S.A., Hawthrone, K.M., Aliu, O., Hicks, P.D., Chen, Z. \& Griffin, I.J. (2007). An Inulin-Type Fructan Enhances Calcium Absorbtion Primarily via an Effect on Colonic Absorption in Human. The Journal of Nutrition, 137, 2208-2212.

Baron, R. (2006). Anatomy and Ultrastructur of Bone Histogenesis, Growth, and Remodeling. Boston: Longwood Avenue.

Buckle, K. A., Edwards, R. A., Fleet, G. H., \& Wootton, M. (2010). Ilmu Pangan. Jakarta: UI-Press.

Chen, J. (2003). Overview of sea cucumber farming and sea ranching practices in China. SPC Beche-de-mer Information 18 Bulletin, 18-23.

Du, X. Q., Greenfield, H., Fraser, D.R., Ge, K.Y., Liu, Z.H., He, W. (2002). Milk consumption and bone mineral content in chinese adolescent girl. Bone, 30, 521-528.

Desnilasari, D. (2014). Formulasi Minuman Sinbiotik dengan Penambahan Puree Pisang Ambon (Musa paradisiacavarsapientum) dan Inulin Menggunakan Inokulum Lactobacillus casei. Jurnal Agritech, 34(03).

Fajriyah, Iftah. (2010). Pengaruh Penambahan Sukrosa pada Susu Sapi Terhadap Karakteristik Yoghurt yang Dihasilkan. Skripsi. Jurusan Peternakan Universitas Sebelas Maret.

Griffin, I. J., Davila, P. M., \& Abrams, S. A. (2002). Nondigestible oligosaccharides and calcium absorption in girls with adequate calcium intakes. British Journal of Nutrition, 87, 187-191.

Guillerminet, F., Beaupied, H., Fabien-Soulé, V., Tomé, D., Benhamou, C.L., Roux, C. \& Blais, A. (2010). Hydrolyzed collagen improves bone metabolism and biomechanical parameters in ovariectomizedmice: $A n$ in vitro and in vivo study. Bone, 46(3), 827-834.

Iwai, K., Hasegawa, T., Taguchi Y., Morimatsu, F., Sato, K., Nakamura, Y., Higashi, A., Kido, Y., Nakabo, Y., \& Ohtsuki, K. (2005). Identification of Food-Derived Collagen Peptides in Human Blood after Oral Ingestion of Gelatin Hydrolysates. Journal of Agricultural and Food Chemistry, 53, 6531-6536.
Jahari, A. B. \& Prihartini, S. (2007). Risiko Osteoporosis di Indonesia. Jurnal Gizi Indonesia Puslitbang Gizidan Makanan Depkes RI, 30(1), 1-11.

Junaidi, I. (2007). Osteoporosis. Jakarta: Gramedia.

Koswara, S. (2009). Teknologi Pengolahan Susu. UNIMUS. Diakses dari bkp.madiunkab.go.id/downlot. php?file=TEKNOLOGI-PENGOLAHAN-SUSU.pdf

Kustiariyah. (2007). Teripang sebagai Sumber Pangan dan Bioaktif. Buletin Teknologi Hasil Perikanan, 10(1), 1-8.

Manik, E. (2006). Olahan Susu. Jakarta: Pusat Unit Pangan dan Gizi.

Maheswari, R. R. (2004). Penanganan dan Pengolahan Hasil Ternak Perah. Institut Pertanian Bogor.

Mirdhayati, I., Handoko, J., \& Putra, K. U. (2007). Mutu Susu Segar di UPT Ruminansia Besar Dinas Peternakan Kabupaten Kampar Provinsi Riau. Jurnal Peternakan, 5, 14-21.

Nahak, R. J., Khotimah, S., \& Turnip, M. (2014). Aspek mikrobiologis susu sapi murni dengan penambahan sari rimpang Bangle (Zingiber cassumunar Roxb). Jurnal Protobiont, 3(3), 69-74.

Nicol, W. M. (1979). Sucrose and Food Technology. London: Applied Science Publisher.

Scholz-ahrens, K. E., Ade, P., Marten, B., Weber, P., Timm, W., Yahya, A., \& Glu, C. (2007). Prebiotics, Probiotics, and Synbiotics Affect Mineral Absorption, Bone Mineral Content, and Bone Structure. The Journal of Nutrition, 4, 838S-846S.

Penggalih, M. H. S. T. (2015). Pengaruh Prebiotik, Kalsium, dan Kolagen Terhadap Pembentukan Massa Tulang Tikus dengan Osteoporosis. Yogyakarta.

Permatasari, T. A. E. (2011). Hubungan Asupan Kalsium dan Faktor Risiko Lainnya dengan Kejadian Osteoporosis pada Kelompok Dewasa Awal di Wilayah CiputatTangerang Selatan. Jurnal Kedokterandan Kesehatan 2, $7(2)$.

Rakhmah, Y. (2012). Studi Pembuatan Bolu Gulung dari Tepung Ubi Jalar (Ipomoea batatas L.). Universitas Hasnuddin.

Robling, A., Castillo, A., \& Turner, C. (2006). Biomechanical and Molecular Regulation of Bone Remodeling. Annual Review of Biomedical Engineering, 8, 455-498.

Widodo, W. (2002). Bioteknologi Fermentasi Susu. Malang.

Winarno, F. G. (2004). Kimia Pangan dan Gizi. Jakarta: PT Gramedia Pustaka Utama.

Zuhra, C. F. (2006). Flavor (Citarasa). Universitas Sumatera Utara. 